a Mars touchdown. Perhaps this confidence permeated through to the lander, which, after letting go of its parachute, seems to have mistakenly believed it was safe on the ground, and turned off its braking thrusters with at least 2 kilometres to go.

As Nature went to press, space-agency officials remained reluctant to say the probe had crashed. But it seems safe to say that a glitch in a sensor or computer meant that Schiaparelli covered the remaining distance somewhat quicker than expected, and arrived with the velocity of a bullet train. Indeed, NASA's Mars Reconnaissance Orbiter has spotted what seems to be a 15-metre-by-40-metre impact zone.

ESA has little time to mourn. As we report on page 435, the mission was part of ExoMars, a wider two-part programme run jointly with the Russian space agency, Roscosmos. It was supposed to demonstrate the ability to land on Mars ahead of a second planned trip, an ambitious rover mission scheduled for 2020 , and the coming months will now see frenetic activity to piece together exactly what went wrong with the landing and what can be done to fix it. Anxiety is back, which is no bad thing.

In the days after the crash, ESA's public message was achingly positive. Director-general Johann-Dietrich Wörner and a series of press releases sought to focus public attention on both the success of Schiaparelli's mothership - the Trace Gas Orbiter, which entered orbit around Mars on the same day as the crash - and the fact that the lander sent back enough data to both study what went right and diagnose what went wrong (in contrast, for example, to the ESA-operated but British-led Beagle 2, which disappeared on Christmas Day 2003; its fate could not be determined until it was spotted on the surface some 11 years later).

Such positive spin cannot distract from a spacecraft crash — even one billed as a test. But ESA scientists are correct that the mission was largely a success. For a start, the orbiter is the more scientifically important part: it is intended to track the intriguing origins of Martian methane, and to act as a communications relay for the 2020 rover. As for Schiaparelli, there is no doubt that it is better for the test device to crash and to provide lessons, than for some fatal flaw to emerge only during the landing of the much more expensive rover or any other future mission.

Still, in two short months, ESA directors will have to explain the very public failure of the landing as they discuss the future of the 2020 mission at this year's ministerial council. Technologically, there should be no problem. Although investigations are still under way, so far all signs point to the failure being something that will be relatively quick and easy to put right. But politically, there is danger. The mission still needs around another $€ 300$ million (US $\$ 326$ million) from the public purse. exploration, failure goes hand in hand with progress."
"In space

At least publicly, Wörner is stubbornly optimistic about how little effect the crash could have on ministers' willingness to stump up the cash. Asked about this at a press briefing, Wörner said he saw no reason for ministers to view the 2016 mission as any less of a success than he does. Behind the scenes, however, scientists are more nervous. With austerity continuing to reign across Europe, politicians may be wary of committing millions more to a venture whose risk seems to have shot up.

But ministers would be wrong to hesitate. Not only because experience from Schiaparelli's crash will aid the ExoMars 2020 landing, but because in something as absurdly hard as space exploration, failure goes hand in hand with progress. ESA's recent string of successes - including the pioneering Rosetta comet mission and a prototype gravitational-wave detector, the LISA pathfinder - may have made such feats look easy, but about half of attempts to land on Mars fail, and the margin between failure and success can be miniscule.

So far, only NASA has successfully landed and operated on Mars (the Soviet probe Mars 3 reached the surface in 1971, but transmitted for only 20 seconds). Although Schiaparelli's failure means that Europe can't yet claim to have joined NASA in the big leagues, without missions such as ExoMars 2020, it never will. ESA has a budget less than one-third the size of NASA's, but its ambitions are growing, and the European population is no less hungry for science and exploration than is its US counterpart. Failure should not be a reason to draw back, but an impetus to push forward.

\section{Rewriting history}

\section{A genetic analysis of HIV clears the man wrongly dubbed the source of the epidemic.}

$\mathrm{I}$ n 1982, the Canadian air steward Gaétan Dugas wrote of his worsening illness in a letter to Ray Redford, his former lover. Believing he had what was being called "gay cancer", Dugas had shaved his hair ahead of expected chemotherapy. He felt nude without it, he said. Like an alien.

Dugas told friends he was ready to fight and beat the cancer, but he died in 1984. By then, scientists and public-health officials had a new, more formal, name for the illness that claimed his life - HIV/AIDS. Dugas was given a different label, too. As the attention of politicians and journalists was drawn to the unfolding crisis, he was identified as 'Patient Zero' of the US epidemic. He was demonized as a knowing and callous reservoir of infection and as a deliberate transmitter of disease. He was regularly compared with Mary Mallon, better known as Typhoid Mary - the cook who, several decades earlier, ignored instructions not to prepare food, and infected dozens in New York City with that bacterial disease.

Thirty years on, samples of the virus that closed down Dugas's immune system still exist. And in a research paper this week, disease scientists report how they have analysed its genetic sequence (M. Worobey et al. Nature http://dx.doi.org/10.1038/nature19827; 2016). The results are important for two reasons. In clinical terms, they show that Dugas's virus was, in many ways, unexceptional. And in human terms, they clear his name.

Dugas was identified as Patient Zero in a 1987 book about the AIDS epidemic, And the Band Played On (St. Martin's), by journalist Randy Shilts, who died in 1994. Shilts painted Dugas as a villain, and turned a typographical curiosity into a badge of dishonour. US scientists had spoken to Dugas as they investigated a cluster of cases of the new syndrome in Los Angeles in 1982. Because he didn't live in the state, his case notes were marked as Patient $\mathrm{O}$ for "Outside of California". When vocalized, the designation became muddled with the number zero. As Shilts said when he first heard the description: "Ooh, that's catchy."

The author introduced the air steward to the world as the original sinner. A man whose reckless behaviour and disregard for the health of his (many) sexual partners helped the AIDS epidemic to take hold. He became known as a lover driven by hate, and a foreigner who brought death and disease to US shores. The myth helped to drive the political response to the disease. It was used to demand laws to stop the deliberate transmission of the virus, and fuelled hostility towards a community that many believed had brought the disease on themselves as a perverse condemnation of their lifestyle.

Medical historians have chipped away at the pernicious story of Dugas as Patient Zero for years. They have pointed out, for example, how he helped epidemiologists to trace a significant number of his sexual partners. And how the scientific advice at the time was contradictory and distrusted by people whose sexuality medics had considered a psychiatric problem until just a decade earlier.

The latest genetic analysis completes the exoneration. The virus arrived in New York City from the Caribbean around 1970. There is nothing in the samples from Dugas that implicate him and his behaviour as key to its subsequent rapid spread. In his 1982 letter, Dugas wrote that "my mind is finding peace again". RIP. 